\title{
Parasellar Chronic Inflammatory Disease Presenting Tolosa-Hunt Syndrome, Hypopituitarism and Diabetes Insipidus: A Case Report
}

\author{
SeIjI HAMA, KazUnORI ARITA, KaORU KURISU, MASAYUKi SUMIDA, AND KanjI KURIHARA* \\ Department of Neurosurgery, Hiroshima University School of Medicine, Hiroshima 734, and \\ *Department of Pathology, Red Cross Hospital and Atomic-Bomb Survivors Hospital, Hiroshima 734, Japan
}

\begin{abstract}
We describe a 60-year-old man with a history of Tolosa-Hunt syndrome associated with intermittent painful ophthalmoplegia and a visual disturbance on the left side, who presented with signs and symptoms of severe hypoadrenalism and diabetes insipidus. Magnetic resonance imaging demonstrated enlargement of the hypophysis and infundibulum and left cavernous sinus. An endocrinologic study revealed anterior pituitary dysfunction and diabetes insipidus. The patient underwent a transsphenoidal biopsy which revealed chronic inflammation in the hypophysis, mucosa of the sphenoid sinus, and dura mater. The patient was treated with steroids that decreased the size of the hypophysis and infundibulum, but the symptoms of anterior pituitary insufficiency and diabetes insipidus have persisted. The chronic inflammation of the hypophysis and infundibulum is thought to have spread from the cavernous sinus.
\end{abstract}

Key words: Parasellar chronic inflammatory disease, Tolosa-Hunt syndrome, Hypopituitarism, Diabetes insipidus

(Endocrine Journal 43: 503-510, 1996)

AS THE orbit, cavernous sinus, paranasal sinus and sella turcica are surrounded by bone and dura mater, inflammation occurring in one structure does not easily spread to another. Thus chronic nonspecific inflammation is classified according to the main site of inflammation, as orbital pseudotumor, inflammation in the orbit [1, 2]; Tolosa-Hunt syndrome in the cavernous sinus; $[3,4]$ and hypophysitis in the sella turcica [5-8]. We describe a patient who had chronic inflammation in the hypophysis and infundibulum that probably originated in a previously identified chronic nonspecific inflammation in the cavernous sinus.

\section{Received: December 25, 1995}

Accepted: May 14, 1996

Correspondence to: Dr. Seiji HAMA, Department of Neurosurgery, Hiroshima University School of Medicine, 1-2-3 Kasumi, Minami-ku, Hiroshima 734, Japan

\section{Case Report}

In June, 1988, a 60-year-old Japanese man, who had been under treatment for hypertension for the last 15 years, began to have intermittent, painful left ophthalmoplegia. He was admitted to a local hospital, where he was treated with steroids, which provided some relief, and he was discharged. Two years later, he also noted decreasing visual acuity in his left eye, and he consulted the Department of Neurosurgery, Hiroshima University School of Medicine.

Magnetic resonance (MR) imaging demonstrating enlargement of the left cavernous sinus and occlusion of the left internal carotid artery. He was again started on a regimen of $3 \mathrm{mg}$ of betamethasone per day, which provided some relief, but the symptoms recurred when the steroid treat- 
ment was tapered off. A presumptive diagnosis of Tolosa-Hunt syndrome was made. Treatment with $10 \mathrm{mg}$ of betamethasone was started. The symptoms diminished and eventually disappeared with steroid treatment, the dosage of which was tapered off over 1 year and was stopped in the beginning of November, 1993. During the month of December, 1993, he gradually developed generalized fatigue, vomiting and dry skin. On December 24, his serum sodium level was $132 \mathrm{mEq} / l$ (normal: 137-149), and serum cortisol and plasma ACTH levels were not detectable. A diagnosis of hypoadrenalism was made, and he was treated with 25 $\mathrm{mg}$ of cortisone acetate daily. Three weeks later, he also began to show signs of polyuria and polydipsia. These symptoms were followed by rapid deterioration in his condition requiring bedrest, and he was admitted to our hospital on January 13, 1994.
On admission, he complained of severe generalized fatigue and cold intolerance. Physical examination revealed slight obesity, with a weight of 75 $\mathrm{kg}$ and height of $170 \mathrm{~cm}$. His axillary and pubic hair were sparse. His temperature was $39.2^{\circ} \mathrm{C}$, blood pressure $102 / 68 \mathrm{mmHg}$, and pulse $88 / \mathrm{min}$. His tongue and skin were dry, suggesting severe dehydration. While he was well-oriented on mental status examination, ocular examination revealed slight paresis of the left 6 th cranial nerve and atrophy of the left optic fundus. The remainder of the neurological findings were within normal limits.

His urine volume was $4500 \mathrm{ml}$ a day, and the urinary specific gravity was 1.007 . The white blood cell count $\left(18900 / \mathrm{mm}^{3}\right)$ and the C-reactive protein concentration $(9.7 \mathrm{mg} / \mathrm{d} l)$ were suggestive of inflammation. No antipituitary antibodies were detected, but the antinuclear antibody titer was 1:160 (nucleolar type) (Table 1).

Table 1. Laboratory data on admission

\begin{tabular}{|c|c|c|c|c|c|}
\hline \multicolumn{3}{|l|}{ Complete blood-count } & \multicolumn{3}{|l|}{ Endocrinologic examination } \\
\hline White blood cells & $18900 / \mathrm{mm}^{3}$ & $(4900-9000)$ & Cortisol & $1.6 \mu \mathrm{g} / \mathrm{d} l$ & $(4.5-18.0)$ \\
\hline Neutrophils & $58.4 \%$ & $(46.1-63.3)$ & ACTH & $<5 \mathrm{pg} / \mathrm{ml}$ & $(9-52)$ \\
\hline Lymphocytes & $24.2 \%$ & $(27.5-43.1)$ & TSH & $0.30 \mu \mathrm{U} / \mathrm{m} l$ & $(0.48-4.82)$ \\
\hline Monocytes & $10.2 \%$ & $(3.8-6.2)$ & Free T3 & $4.8 \mathrm{pg} / \mathrm{ml}$ & $(3.9-5.5)$ \\
\hline Eosinophils & $0.5 \%$ & $(0.8-5.0)$ & Free $\mathrm{T} 4$ & $0.8 \mathrm{ng} / \mathrm{d} l$ & $(1.1-1.9)$ \\
\hline Basophils & $6.5 \%$ & $(0.2-1.3)$ & PRL & $3.1 \mathrm{ng} / \mathrm{ml}$ & $(2.1-17.8)$ \\
\hline Red blood cells & $395 \times 10^{4} / \mathrm{mm}^{3}$ & $(438-534)$ & $\mathrm{LH}$ & $0.3 \mathrm{mIU} / l$ & $(0.9-10.1)$ \\
\hline Hemoglobin & $11.8 \mathrm{~g} / \mathrm{d} l$ & $(13.9-16.9)$ & FSH & $3.1 \mathrm{mIU} / \mathrm{l}$ & $(0.4-6.2)$ \\
\hline Hematocrit & $35.9 \%$ & $(40.1-48.6)$ & Antidiuretic hormone & $0.5 \mathrm{pg} / \mathrm{ml}$ & $(0.3-4.2)$ \\
\hline \multirow[t]{2}{*}{ Platelets } & $28.8 \times 10^{4} / \mathrm{mm}^{3}$ & $(15.8-35.8)$ & & & \\
\hline & & & Serological test & & \\
\hline Blood chemistry & & & TPHA & - & $(-)$ \\
\hline Total protein & $7.1 \mathrm{~g} / \mathrm{d} l$ & $(6.5-8.3)$ & Rheumatoid factor & $<6.0 \mathrm{IU} / \mathrm{ml}$ & $(<6.0)$ \\
\hline Alkaline phosphatase & $166 \mathrm{IU} / l$ & $(9.0-340)$ & $\mathrm{ACE}$ & $17.8 \mathrm{U} / l$ & $(7.0-25.0)$ \\
\hline GOT & $23 \mathrm{IU} / l$ & $(8-40)$ & Antinuclear antibody & $1: 160$ & $(<1: 20)$ \\
\hline GPT & $22 \mathrm{IU} / l$ & $(0-40)$ & & Nucleolar type & \\
\hline Blood ureanitrogen & $12 \mathrm{mg} / \mathrm{d} l$ & $(8-15)$ & Antipituitary antibodies & - & $(-)$ \\
\hline Creatinine & $1.61 \mathrm{mg} / \mathrm{d} l$ & $(0.57-0.87)$ & & & \\
\hline $\mathrm{Na}$ & $134 \mathrm{mEq} / l$ & $(137-149)$ & Cerebrospinal fluid & & \\
\hline $\mathrm{K}$ & $3.3 \mathrm{mEq} / \mathrm{l}$ & $(3.7-5.0)$ & Cell count & $27 / 3$ & \\
\hline $\mathrm{Cl}$ & $98 \mathrm{mEq} / \mathrm{l}$ & $(98-109)$ & Neutrophils & $15 / 3$ & \\
\hline $\mathrm{Ca}$ & $4.5 \mathrm{mEq} / \mathrm{l}$ & $(4.3-5.5)$ & Lymphocytes & $12 / 3$ & \\
\hline $\operatorname{Ig} G$ & $1700 \mathrm{mg} / \mathrm{d} l$ & $(1048-1646)$ & Glucose & $58 \mathrm{mg} / \mathrm{d} l$ & $(50-70)$ \\
\hline $\operatorname{Ig} A$ & $486 \mathrm{mg} / \mathrm{d} l$ & $(146-340)$ & Protein & $61 \mathrm{mg} / \mathrm{d} l$ & $(15-40)$ \\
\hline $\operatorname{Ig} \mathrm{M}$ & $177 \mathrm{mg} / \mathrm{d} l$ & $(79-179)$ & Culture & no growth & (no growth) \\
\hline Ig E & $24.2 \mathrm{mg} / \mathrm{d} l$ & $(<448.8)$ & & & \\
\hline $\mathrm{C} 3 \mathrm{c}$ & $79 \mathrm{mg} / \mathrm{d} l$ & $(72-104)$ & & & \\
\hline $\mathrm{C} 4$ & $33 \mathrm{mg} / \mathrm{d} l$ & $(20-38)$ & & & \\
\hline
\end{tabular}

GOT, glutamic oxaloacetic transaminase; GPT, glutamic pyruvic transaminase; ACE, angiotensin converting enzyme; TPHA, treponema pallidum hemagglutination; Antipituitary antibodies, antibodies reacting against plasma membrane of AtT-20 and GH3 and cytoplasm of rat pituitary cells (Biomedical Laboratories, Saitama, Japan). The values in brackets are standard normal values. 
Table 2. Endocrine tests performed on admission and 4 months after steroid therapy

\begin{tabular}{|c|c|c|c|c|}
\hline & & & On admission & $\begin{array}{l}4 \text { months after } \\
\text { steroid therapy }\end{array}$ \\
\hline \multirow{4}{*}{$\begin{array}{l}\text { Insulin-induced } \\
\text { hypoglycemia }\end{array}$} & Blood sugar & $\mathrm{mg} / \mathrm{d} l$ & $84 \rightarrow 41$ & $100 \rightarrow 55$ \\
\hline & $\mathrm{GH}$ & $\mathrm{ng} / \mathrm{ml}$ & $0.39 \rightarrow 0.47$ & $0.1 \rightarrow 0.2$ \\
\hline & Cortisol & $\mu \mathrm{g} / \mathrm{d} l$ & N.D. $\rightarrow$ N.D. & $1.5 \rightarrow 1.5$ \\
\hline & ACTH & $\mathrm{pg} / \mathrm{ml}$ & 6 & 7.4 \\
\hline \multirow{4}{*}{ TRH $(500 \mu \mathrm{g})$} & TSH & $\mu \mathrm{U} / \mathrm{ml}$ & $0.27 \rightarrow 0.91$ & N.D. $\rightarrow 0.34$ \\
\hline & PRL & $\mathrm{ng} / \mathrm{ml}$ & $2.5 \rightarrow 5.1$ & $2.0 \rightarrow 3.6$ \\
\hline & Free T3 & $\mathrm{pg} / \mathrm{m} l$ & 3.2 & 5.7 \\
\hline & Free T4 & $\mathrm{ng} / \mathrm{d} l$ & 0.9 & 1.6 \\
\hline \multirow{2}{*}{ LHRH $(100 \mu \mathrm{g})$} & LH & $\mathrm{mIU} / \mathrm{ml}$ & $0.5 \rightarrow 0.9$ & $0.3 \rightarrow 1.9$ \\
\hline & FSH & $\mathrm{mIU} / \mathrm{ml}$ & $1.9 \rightarrow 4.3$ & $2.4 \rightarrow 5.8$ \\
\hline
\end{tabular}

Plasma ACTH and serum Free T3, Free T4 were measured before endocrine tests. N.D.=not detectable.

\section{Endocrinologic studies}

For the $48 \mathrm{~h}$ immediately preceding the endocrinologic examination, the patient did not take any cortisone acetate. Prestimulation values of $\mathrm{ACTH}$, Free T3, Free T4 were below the normal range. The responses were diminished or impaired for GH and cortisol to insulin-induced hypoglycemia, $\mathrm{LH}$ and FSH to intravenous LHRH $(100 \mu \mathrm{g})$, and TSH and PRL to intravenous TRH (500 $\mu \mathrm{g}$ ) (Table 2). The results of a water deprivation test are shown in Table 3. The urinary osmolality and plasma antidiuretic hormone concentration were low despite high plasma osmolality, and his diabetes insipidus was confirmed to be of central origin [9].

Computed tomography demonstrated homogeneously enhanced enlargement of the left cavernous sinus and destruction of the sellar floor and the tuberculum sellae. MR imaging demonstrated enlargement of the left cavernous sinus and hypophysis, thickening of the infundibulum and obstruction of the internal carotid artery in the left suprasellar lesion. The signal intensity of these lesions was strongly increased by the administration of gadolinium (Fig. 1). The normal high intensity in the posterior pituitary lobe was absent. A cerebral angiogram revealed irregular narrowing of the left internal carotid artery with obstruction in the cavernous portion, but no lesion in the right internal carotid artery.
Table 3. Water deprivation test

\begin{tabular}{cccccc}
\hline $\begin{array}{c}\text { Time } \\
(\mathrm{min})\end{array}$ & $\begin{array}{c}\text { Body } \\
\text { weight } \\
(\mathrm{kg})\end{array}$ & $\begin{array}{c}\text { Urine } \\
\text { volume } \\
(\mathrm{ml} / \mathrm{h})\end{array}$ & $\begin{array}{c}\text { Urine } \\
\text { osmolality } \\
(\mathrm{m} \text { (sm } / \mathrm{kg})\end{array}$ & $\begin{array}{c}\text { Serum } \\
\text { osmolality } \\
(\mathrm{mOsm} / \mathrm{kg})\end{array}$ & $\begin{array}{c}\mathrm{ADH} \\
(\mathrm{pg} / \mathrm{ml})\end{array}$ \\
\hline 0 & 75.6 & & 174 & 272 & 0.7 \\
60 & 75.2 & 350 & 170 & 274 & 0.5 \\
120 & 74.9 & 250 & 143 & 279 & 0.4 \\
180 & 74.4 & 300 & 90 & 279 & $<0.3$ \\
240 & 73.9 & 500 & 105 & 287 & $<0.3$ \\
300 & 73.3 & 500 & 98 & 286 & 0.7 \\
\hline
\end{tabular}

$\mathrm{ADH}$, antidiuretic hormone.

\section{Operation}

After we obtained the patient's informed consent, we performed transsphenoidal exploration of the sella turcica in order to rule out neoplastic disease. The mucosa in the sphenoid sinus and the dura mater of the sella turcica appeared pale and thickened. The hypophysis also appeared pale. A biopsy of the hypophysis was performed.

\section{Histologic findings}

Hematoxylin and eosin staining of the pathological specimens revealed chronic inflammatory infiltration of the anterior lobe of the hypophysis (Fig. 2). There was no evidence of caseous necrosis or granulomas, and no neuronal elements were 

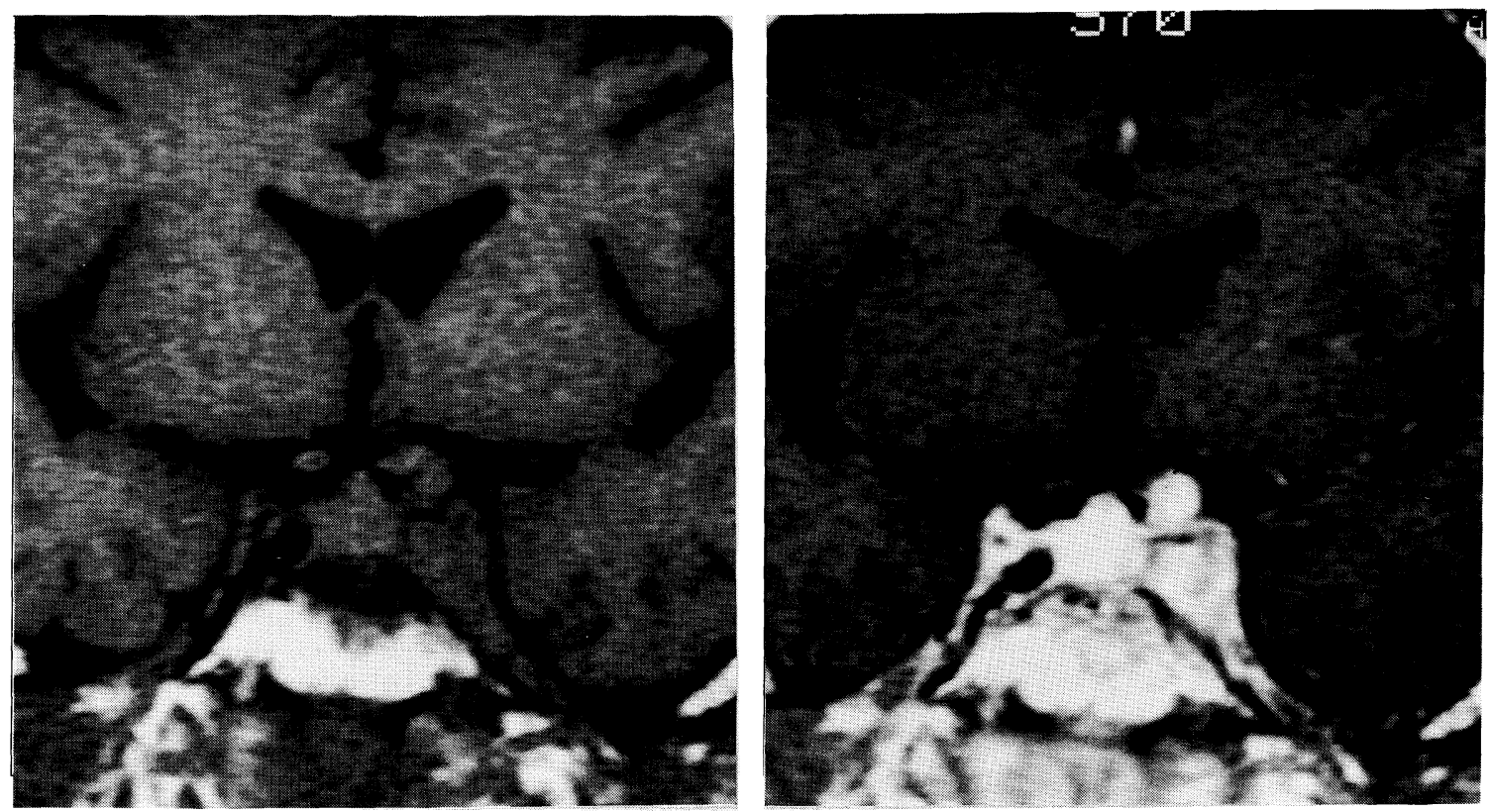

Fig. 1. Left: T1-weighted coronal magnetic resonance (MR) imaging demonstrates enlargement of the left cavernous sinus and pituitary gland and thickening of the infundibulum with iso-intense signal. Right: Gd-DTPA-enhanced coronal MR imaging. Note that the signal intensity of these lesions appears noticeably increased.

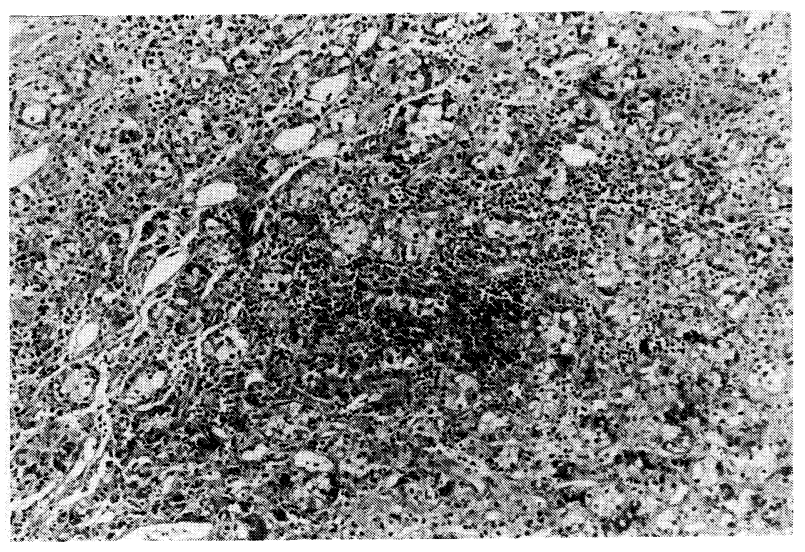

Fig. 2. Low-power photomicrograph of the sellar lesion. There is chronic inflammatory infiltration in the anterior lobe of the pituitary gland. There is no evidence of a granuloma or neoplasm (hematoxylin and eosin, $\times 112$ ).

seen. These findings excluded the possibility of tuberculosis, sarcoidosis, Langerhans-cell histiocytosis, malignant lymphoma, pituitary adenoma or other neoplasms. These inflammatory cells consisted mainly of lymphocytes and histiocytes. Plasmacytic infiltration was mild (Fig. 3). The in-

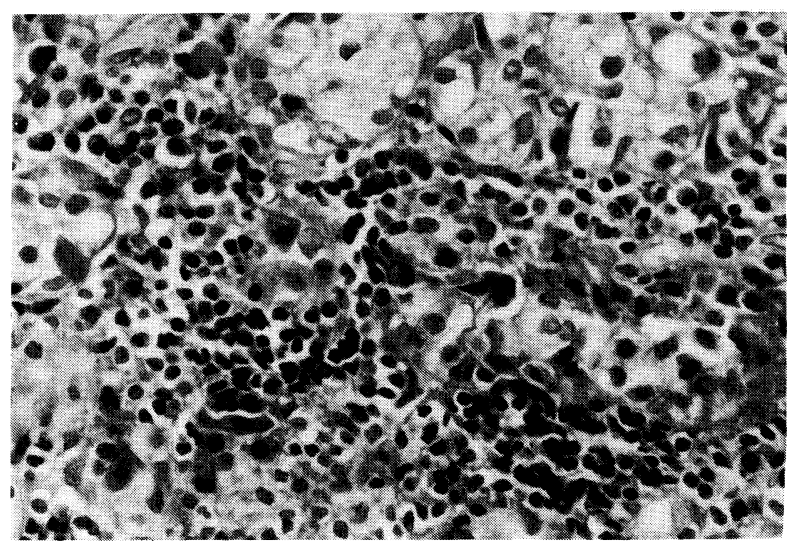

Fig. 3. High-power photomicrograph of the sellar lesion. Marked lymphocytic infiltration and histiocytic infiltration are visible. Plasmacytic infiltration is mild (hematoxylin and eosin, $\times 449$ ).

filtrating lymphocytes were composed of equal numbers of $\mathrm{T}$ and $\mathrm{B}$ cells as demonstrated by immunohistochemical staining with immunoperoxidase markers (MT1 and UCHL1 for T cells; L26 for B cells) (Fig. 4). The histologic sections of tissue from the sphenoid sinus and the dura mater were 

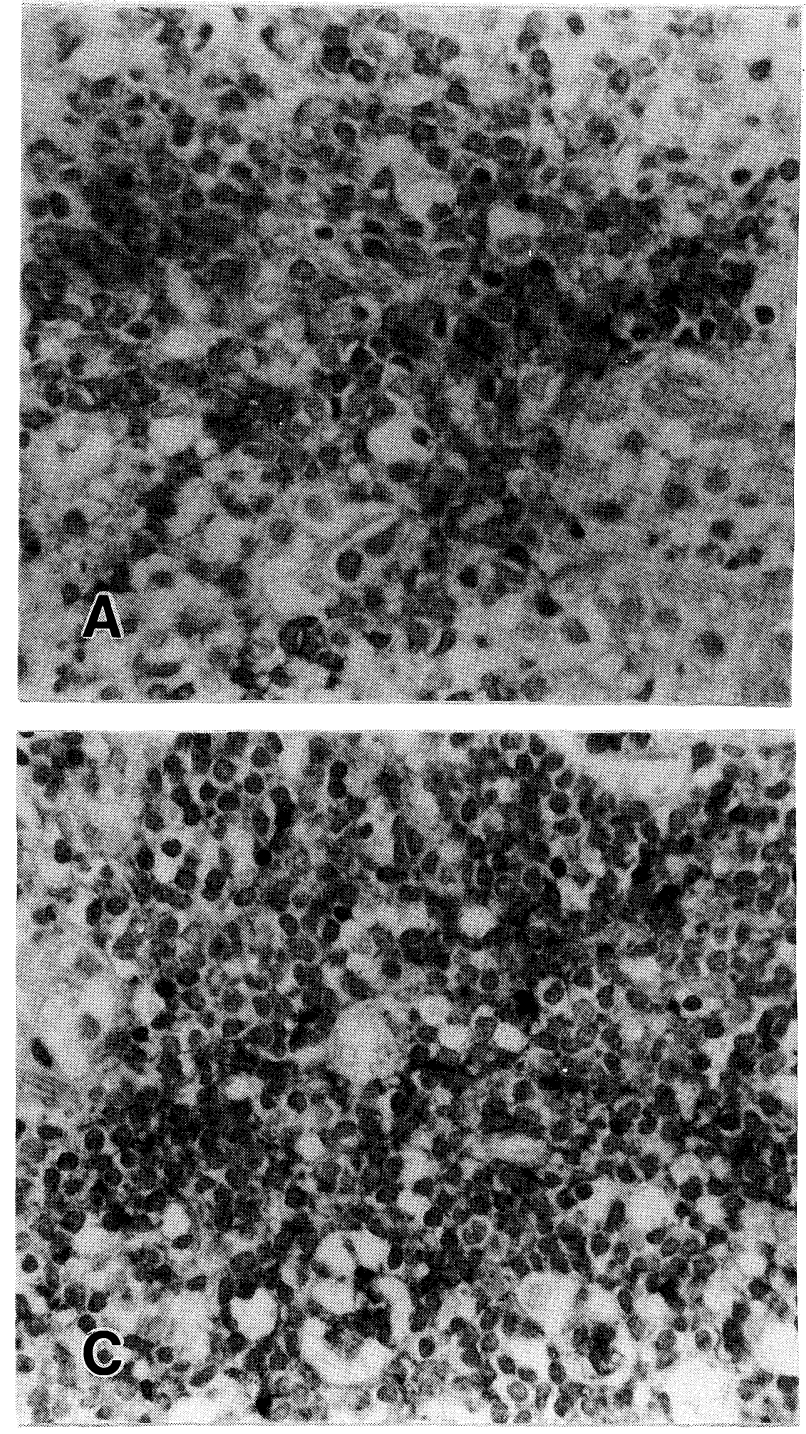

similar to specimens from the sella turcica. These observations suggested direct involvement of the hypophysis and infundibulum caused by inflammation of the cavernous sinus.

\section{Postoperative course}

The patient was treated with intravenous betamethasone (12 mg/day), and the dose was gradually tapered off. After a total of $48 \mathrm{mg}$ had been administered, the medication was changed to oral cortisone acetate $(75 \mathrm{mg} /$ day). The left 6 th nerve palsy eventually resolved, and follow-up MR imaging revealed a decrease in the size of the hypophysis and infundibulum (Fig. 5), but he

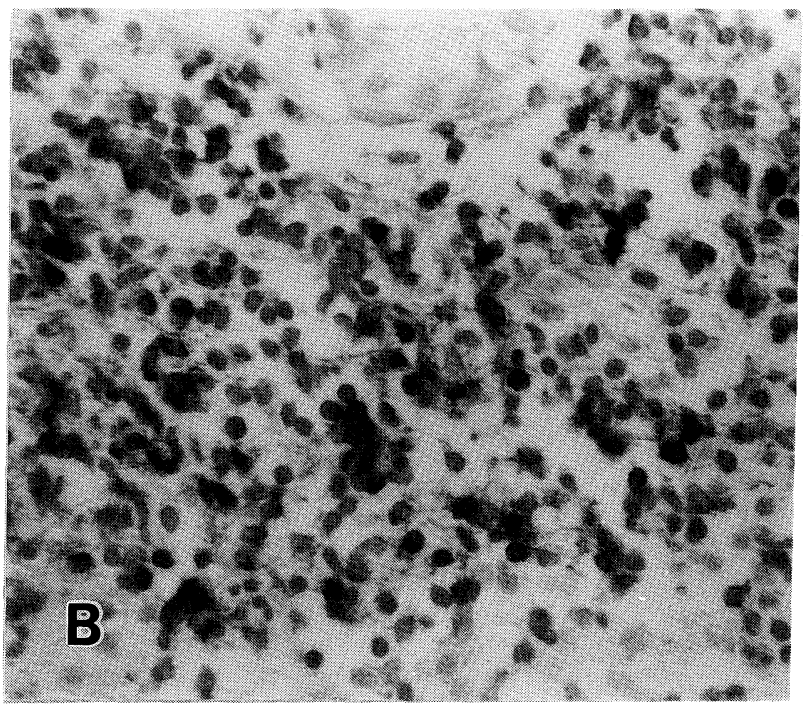

Fig. 4. High-power photomicrographs of the sellar lesion. There is positive immunoperoxidase staining with MT1(A), UCHL1(B) and L26(C). The infiltrating lymphocytes are composed of equal numbers of $T$ and $B$ cells $(\times 389)$.

continued to experience symptoms of severe pituitary dysfunction and diabetes insipidus. On February 27, 1994, he was discharged from our hospital on a replacement therapy regimen consisting of cortisone acetate $(75 \mathrm{mg} /$ day), levothyroxine sodium $(100 \mu \mathrm{g} /$ day) and desmopressin acetate $(7.5$ $\mu \mathrm{g} /$ day). Four months after the start of the postoperative steroid therapy, the pituitary function tests were repeated, and they again showed severe impairment of anterior pituitary gland function (Table 2). At that time he also showed signs of polyuria and polydipsia, and therefore continued to receive cortisone acetate, levothyroxine sodium and desmopressin acetate. 


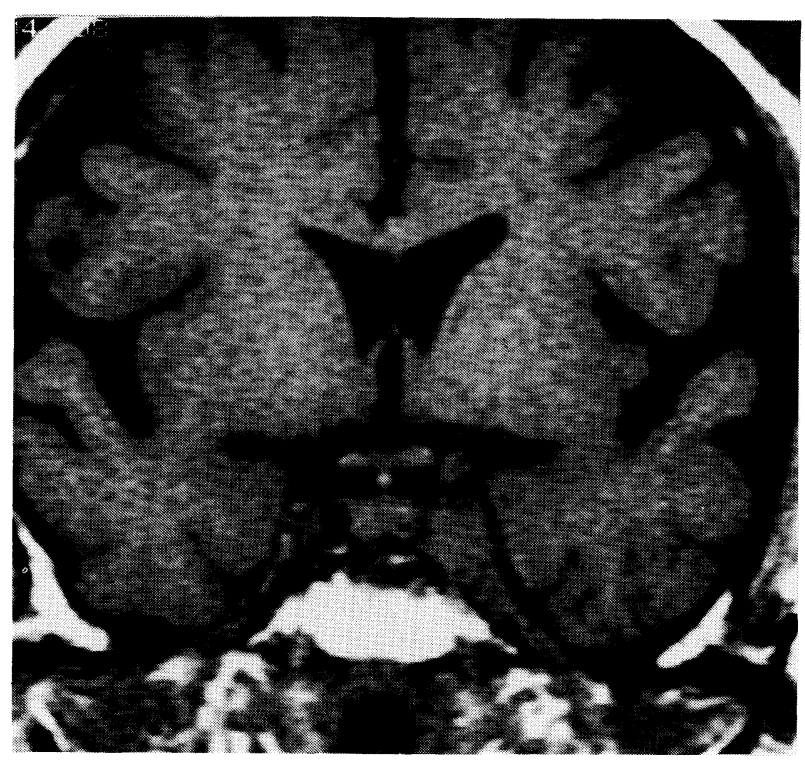

Fig. 5. T1-weighted coronal MR imaging performed 1 month after beginning of steroid therapy demonstrates a reduction in the size of the hypophysis and infundibulum.

\section{Discussion}

The patient initially presented with intermittent painful ophthalmoplegia and a visual disturbance on the left side, and a diagnosis of Tolosa-Hunt syndrome had been made. The steroid treatment regimen was started, but 5 years later he suffered from severe hypoadrenalism and diabetes insipidus as a result of hypophysitis that was presumed, on the basis of the histologic evidence, to have spread from the cavernous sinus. After the start of the betamethasone, MR imaging showed shrinking of the hypophysis and infundibulum, but the anterior pituitary dysfunction and diabetes insipidus persisted. We think that the inflammatory process in the sella turcica regressed as a result of the steroid therapy, but the intrasellar integrity as an endocrine organ had already been destroyed, for which reason the disorders of the anterior and posterior pituitary function continued.

Histologically, the absence of granuloma and Langerhans giant cells excludes tuberculosis and sarcoidosis. The paucity of eosinophils rules out a parasitic cause. In the absence of Langerhans giant cells and underlying vasculitis, Wegener's granulomatous or polyarteritis nodosa may also be excluded. Lymphoma is also unlikely, because of the lack of atypia. Syphilis is also unlikely in view of the negative serology.

Chronic nonspecific inflammation around the sella turcica is classified according to the region of inflammation and is usually thought to be localized within each division, but recently there have been reports of some cases in which inflammation was not confined to one of these regions. Some reports of Tolosa-Hunt syndrome have described the existence of erosion in the sella turcica and invasion of the contralateral cavernous sinus [1013]. It has been suggested that the chronic inflammation in Tolosa-Hunt syndrome may infiltrate adjacent regions. Intraorbital idiopathic chronic inflammatory lesions have been termed orbital pseudotumors. Inflammatory changes in some of these lesions have been found to extend to adjacent regions through the superior orbital or infraorbital fissures [14-16]. Chronic inflammation in the sella turcica is classified according to the gland of main involvement. Lymphocytic infiltration confined mainly to the anterior pituitary is termed lymphocytic adenohypophysitis $[5,7,17-$ 19], and that confined mainly to the neurohypophysis and infundibulum is termed infundibuloneurohypophysitis [8]. These hypophyseal inflammatory diseases have been considered to be autoimmune with a self-limiting course [20-24], but some of these diseases have also been found to have associated lesions of adjacent structures [17-19, 25, 26]. At least some of these parasellar chronic inflammatory changes therefore reflect the spectrum of the single pathologic entity, parasellar chronic inflammatory disease (PSCID), that sometimes spreads from one site to another (Table 4).

Our patient suffered hypopituitarism as a result of chronic sellar inflammatory changes which seem to have spread from the cavernous sinus. Thus this represents another case of PSCID worth reporting because histologic verification of the diagnosis was obtained.

Multifocal fibrosclerosis has recently been reported to involve chronic inflammatory lesions in multiple parasellar compartments such as the orbit, paranasal sinus, cavernous sinus, sella turcica and basal meninges [27-30], but this disease can be distinguished from PSCID by the presence of extracranial lesions, such as retroperitoneal fibro- 
Table 4. Case reports of chronic inflammation of parasellar areas.

\begin{tabular}{|c|c|c|c|c|c|c|c|c|c|}
\hline \multirow{2}{*}{$\begin{array}{l}\text { Case } \\
\text { No. }\end{array}$} & \multirow[b]{2}{*}{ Author } & \multirow{2}{*}{$\begin{array}{l}\text { Age } \\
\text { (yr) } \\
\text { /sex }\end{array}$} & \multicolumn{4}{|c|}{ Manifestations of parasellar inflammation } & \multirow{2}{*}{$\begin{array}{l}\text { Anterior } \\
\text { pituitary } \\
\text { dysfun- } \\
\text { ction }\end{array}$} & \multirow{2}{*}{$\begin{array}{l}\text { Diabetes } \\
\text { insipidus }\end{array}$} & \multirow{2}{*}{$\begin{array}{ll}\text { s } & \text { Clinical or } \\
\text { s } & \text { pathological diagnosis }\end{array}$} \\
\hline & & & $\begin{array}{l}\text { Cavern- } \\
\text { ous } \\
\text { sinus }\end{array}$ & $\begin{array}{l}\text { Sellar } \\
\text { turcica }\end{array}$ & Orbit & $\begin{array}{l}\text { Parana- } \\
\text { sal } \\
\text { sinus }\end{array}$ & & & \\
\hline 1 & Ikeda et al., 1990 [17] & $45 / F$ & + & + & - & - & ++ & + & $\begin{array}{l}\text { Lymphocytic } \\
\text { (adeno) hypophysitis }\end{array}$ \\
\hline 2 & Supler et al., 1992 [19] & $56 / \mathrm{M}$ & + & + & - & - & ++ & - & $\begin{array}{l}\text { Lymphocytic } \\
\text { (adeno) hypophysitis }\end{array}$ \\
\hline 3 & Nussbaum et al., 1991 [18] & $40 / \mathrm{M}$ & + & + & - & - & + & ++ & $\begin{array}{l}\text { Lymphocytic hypophysitis } \\
\text { (infundibuloneurohypo- } \\
\text { physitis) }\end{array}$ \\
\hline 4 & Nussbaum et al., 1991 [18] & $34 / \mathrm{F}$ & + & + & - & - & + & ++ & $\begin{array}{l}\text { Lymphocytic hypophysitis } \\
\text { (infundibuloneurohypo- } \\
\text { physitis) }\end{array}$ \\
\hline 5 & Taylon et al., 1980 [25] & $50 / \mathrm{M}$ & + & + & $?$ & - & $?$ & $?$ & $\begin{array}{l}\text { Giant cell granulomatous } \\
\text { hypophysitis }\end{array}$ \\
\hline 6 & Scanarini et al., 1989 [26] & $57 / \mathrm{M}$ & + & + & - & + & + & - & $\begin{array}{l}\text { Giant cell granulomatous } \\
\text { hypophysitis }\end{array}$ \\
\hline 7 & Noble et al., 1986 [15] & $46 / F$ & + & + & + & - & - & - & Orbital pseudotumor \\
\hline 8 & Ichikawa et al., 1987 [11] & $42 / \mathrm{M}$ & - & + & - & + & - & - & Tolosa-Hunt syndrome \\
\hline 9 & Matsumoto et al., 1989 [12] & $58 / \mathrm{M}$ & + & + & - & + & - & - & Tolosa-Hunt syndrome \\
\hline 10 & Present case & $60 / \mathrm{M}$ & + & + & - & + & + & + & Tolosa-Hunt syndrome \\
\hline
\end{tabular}

sis, mediastinal fibrosis, and sclerosing cholangitis.

In conclusion, the entity in our patient may represent PSCID with histologic verification. Sites of contiguous inflammation should be considered in patients presenting with signs and symptoms suggestive of inflammation in any of these regions.

\section{References}

1. Birch-Hirschfield (1905) Zur Diagnostik und Pathologie der Orbital Tumoren. Berl Dtsch Ophthalmol Ges 32: 127-135.

2. Nugent RA, Rootman J, Robertson WD (1981) Acute orbital pseudotumors: Classification and CT features. AJR 137: 957-962.

3. Tolosa E (1954) Periarteric lesions of the carotid siphon with clinical features of carotid intraclinoid aneurysms. J Neurol Neurology Psychiatry 17: 300302.

4. Hunt WE, Meager JN, LeFever H (1961) Painful ophthalmoplegia: Its relation to indolent inflammation of the cavernous sinus. Neurology 11: 56-62.

5. Goudie RB, Pinkerton PH (1962) Anterior hypophysitis and Hashimoto's disease in a young woman. J Pathol Bacteriol 83: 584-585.

6. Del Pozo JM, Roda JE, Montoya JG (1980) Intrasellar granuloma. Case report. J Neurosurg 53: 717-719.
7. Baskin DS, Townsend JJ, Wilson CB (1982) Lymphocytic adenohypophysitis of pregnancy stimulating a pituitary adenoma: A distinct pathological entity. J Neurosurg 56: 148-153.

8. Imura $H$, Nakao K, Shimatsu A, Ogawa $Y$, Sando T, Fujisawa I, Yamabe H (1993) Lymphocytic infundibuloneurohypophysitis as a cause of central diabetes insipidus. N Engl J Med 329: 683-689.

9. Dashe AM, Cramm RE, Crist CA, Harbener JF, Solomon DH (1963) A water deprivation test for the differential diagnosis of polyuria. J Am Med Assoc 185: 669-703.

10. Polsky M, Janicki PC, Gunderson CH (1979) TolosaHunt Syndrome with sellar erosion. Ann Neurol 6: 129-131.

11. Ichikawa N, Kohnosu T, Tuburaya $K$, Yoshimoto $T$ (1987) Alternating Tolosa-Hunt syndrome with sellar destruction. Clin Neurol 27: 990-995. 
12. Matsumoto T, Kitano I, Tanaka Y, Kuratsu J, Ushio Y (1989) Tolosa-Hunt syndrome: Report of a surgical case. Neurol Med Chir (Tokyo) 29: 944-947.

13. Drevelengas A, Kalaitzoglou I, Tsolaki M (1993) Tolosa-Hunt syndrome with sellar erosion: Case report. Neuroradiology 35: 451-453.

14. Edwards MK, Zauel DW, Gilmor RL, Muller J (1982) Invasive orbital pseudotumor-CT demonstration of extension beyond orbit. Neuroradiology 23: 215-217.

15. Noble SC, Chandler WF, Lloyd RV (1986) Intracranial extension of orbital pseudotumor: A case report. Neurosurgery 18: 798-801.

16. Frohman LP, Kupersmith MJ, Lang J, Reede D, Bergeron RT, Aleksic S, Trasi S (1986) Intracranial extension and bone destruction in orbital pseudotumor. Arch Opthalmol 104: 380-384.

17. Ikeda J, Kuratsu J, Miura M, Kai Y, Ushio Y (1990) Lymphocytic adenohypophysitis accompanying occlusion of bilateral internal carotid arteries-Case report-. Neuro Med Chir (Tokyo) 30: 346-349.

18. Nussbaum CE, Okawara S, Jacobs LS (1991) Lymphocytic hypophysitis with involvement of the cavernous sinus and hypothalamus. Neurosurgery 28: $440-444$.

19. Supler ML, Mickle JP (1992) Lymphocytic hypophysitis: Report of a case in a man with cavernous sinus involvement. Surg Neurol 37: 472-476.

20. Jackson H (1958) Pseudo-tumor of the orbit. Brit J Ophthalmol 42: 212-224.

21. Levine S (1967) Allergic adenohypophysitis: New experimental disease of the pituitary gland. Science 158: 1190-1191.
22. Mayfield RK, Levine JH, Gordon L, Powers J, Galbraith RM, Rawe SE (1980) Lymphoid adenohypophysitis presenting as a pituitary tumor. Am J Med 69: 619-623.

23. Mazzone T, Kelly W, Ensinck J (1983) Lymphocytic hypophysitis associated with antiparietal cell antibodies and vitamin B12 deficiency. Arch Intern Med 143: 1794-1795.

24. McKeel DW (1984) Primary hypothyroidism and hypopituitarism in a young woman. Am J Med 77: 319-330.

25. Taylon C, Duff TA (1980) Giant cell granuloma involving the pituitary gland: Case report. J Neurosurg 52: 584-587.

26. Scanarini M, D'Avella D, Rotilio A, Kitromilis N, Mingrino S (1989) Giant-cell granulomatous hypophysitis: A distinct clinicopathological entity. J Neurosurg 71: 681-686.

27. Comings DE, Skubi KB, Eyes JV, Motulsky AG (1967) Familial multifocal fibrosclerosis. Ann Int Med 66: 884-892.

28. Brazier DJ, Sanders MD (1983) Multifocal fibrosclerosis associated with suprasellar and macular lesions. Br J Ophthalmol 67: 292-296.

29. Berger JR, Snodgrass S, Glaser J, Post MJD, Norenberg M, Benedetto P (1989) Multifocal fibrosclerosis with hypertrophic intracranial pachymeningitis. Neurology 39: 1345-1349.

30. Gartman Jr JJ, Powers SK, Fortune M (1989) Pseudotumor of the sellar and parasellar areas. Neurosugery 24: 896-901. 